\title{
Cost estimation for scale-up of voucher services in Kenya
}

Shubhra Kumar

Smita Sanghrajka

Benjamin Bellows

Population Council

Follow this and additional works at: https://knowledgecommons.popcouncil.org/departments_sbsr-rh

Part of the Demography, Population, and Ecology Commons, International Public Health Commons, Maternal and Child Health Commons, and the Women's Health Commons How does access to this work benefit you? Let us know!

\section{Recommended Citation}

Kumar, Shubhra, Smita Sanghrajka, and Benjamin Bellows. 2013. "Cost estimation for scale-up of voucher services in Kenya," Research report. Nairobi: Population Council. 


\section{COST ESTIMATION FOR SCALE-UP OF VOUCHER SERVICES IN KENYA}

RESEARCH REPORT

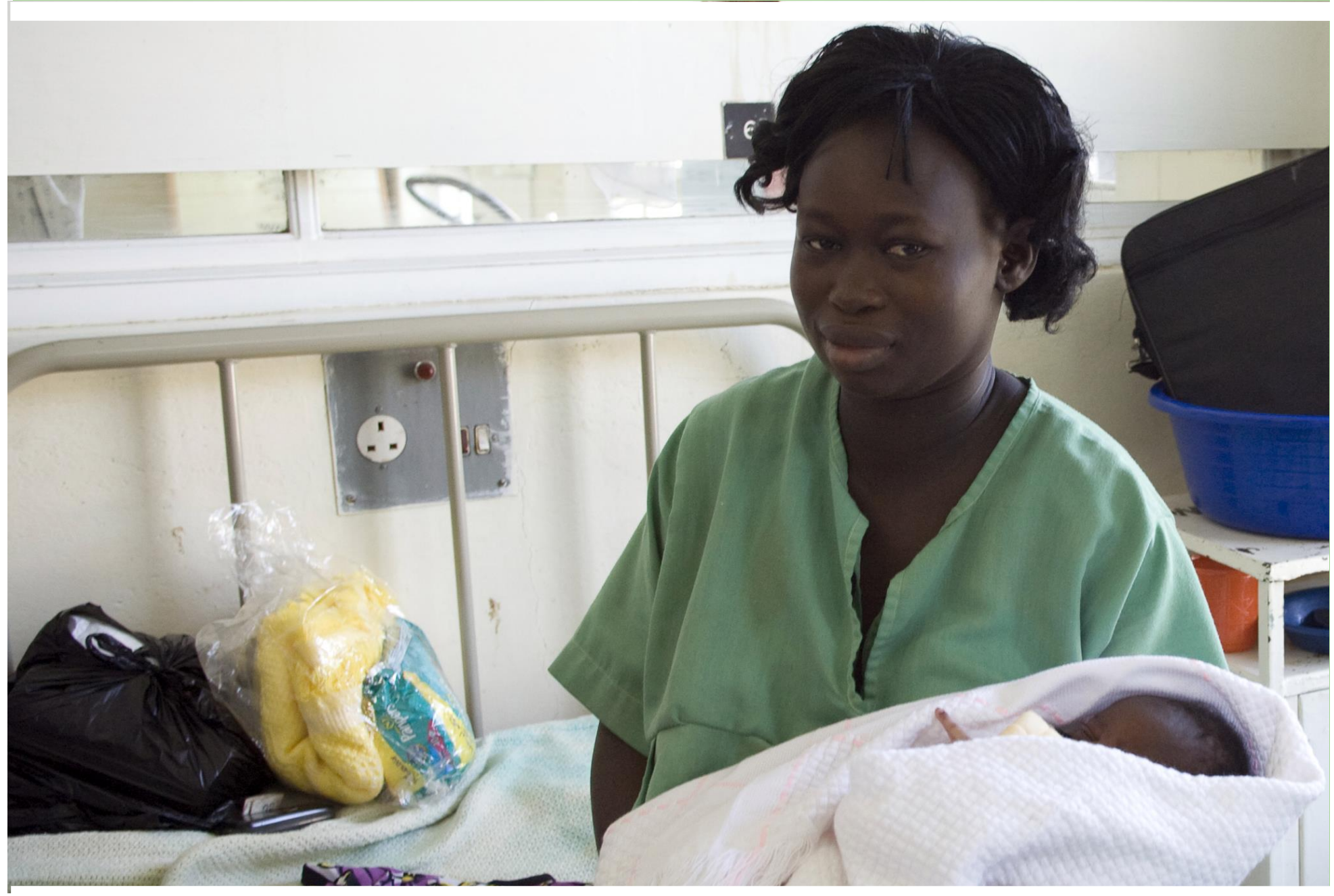

SHUBHRA KUMAR SMITA SANGHRAJKA BEN BELLOWS

APRIL 2013 


\section{COST ESTIMATION FOR SCALE-UP OF VOUCHER SERVICES IN KENYA}

Shubhra Kumar, Population Council

Smita Sanghrajka, independent consultant

Ben Bellows, Population Council 


\section{(2) Population Council}

The Population Council confronts critical health and development issues-from stopping the spread of HIV to improving reproductive health and ensuring that young people lead full and productive lives. Through biomedical, social science, and public health research in 50 countries, we work with our partners to deliver solutions that lead to more effective policies, programs, and technologies that improve lives around the world. Established in 1952 and headquartered in New York, the Council is a nongovernmental, nonprofit organization governed by an international board of trustees.

Population Council

General Accident House

Ralph Bunche Road

Nairobi, Kenya

Tel: +254202713480

Fax: +254202713479

www.popcouncil.org

Suggested citation: Kumar, Shubhra, Smita Sanghrajka, Ben Bellows. 2013.“Cost estimation for scale-up of voucher services in Kenya." Nairobi: Population Council.

Cover photo @

(c) 2013 The Population Council, Inc. 


\section{TABLE OF CONTENTS}

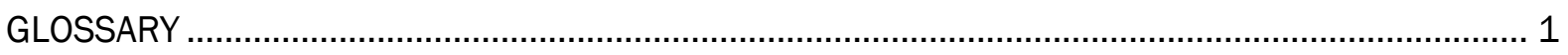

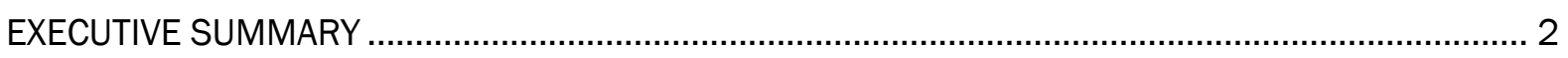

1 CONTEXT: KENYA'S DEMOGRAPHIC INDICATORS AND HEALTH SPENDING ............................ 5

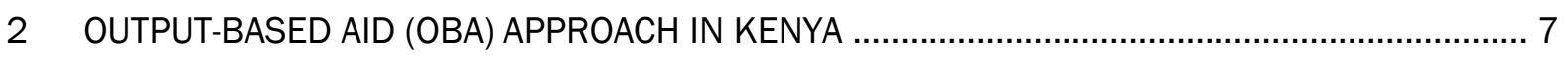

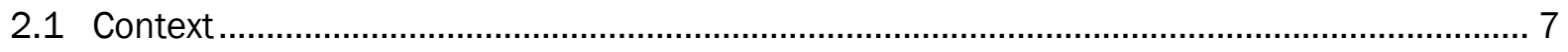

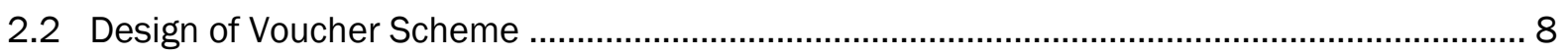

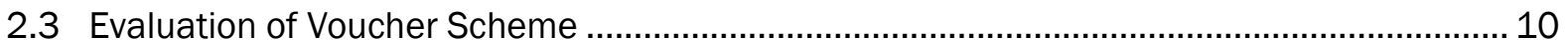

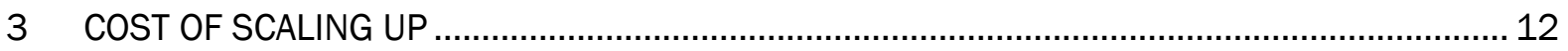

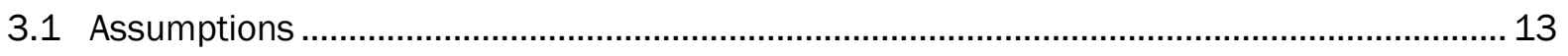

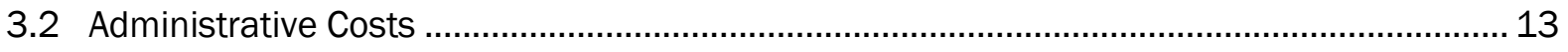

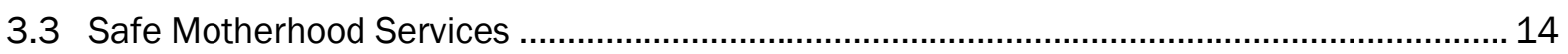

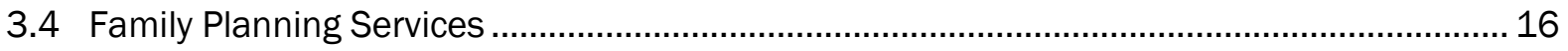

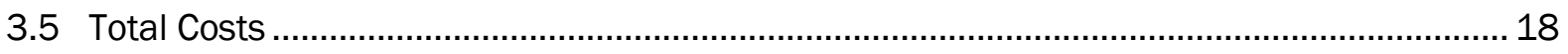

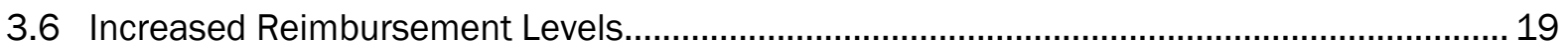

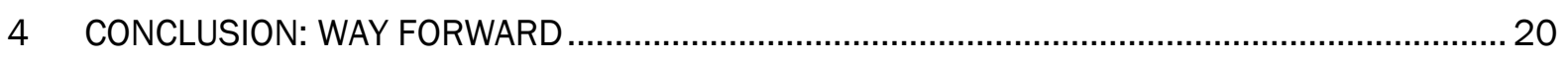

ANNEX A

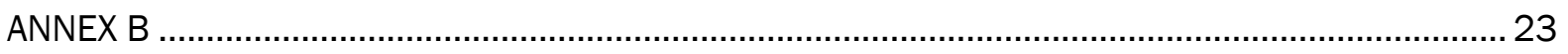

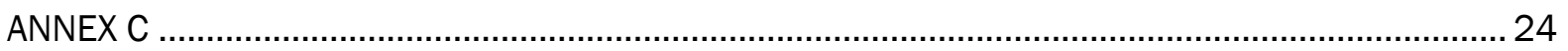

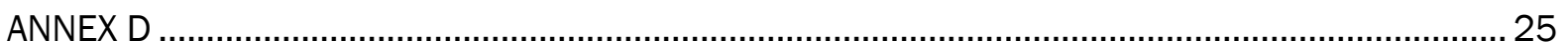

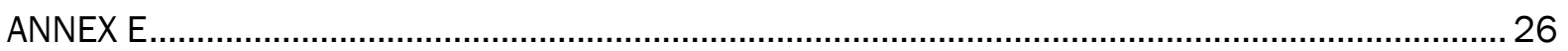

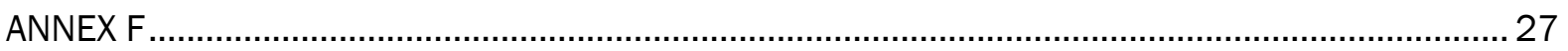


Table 1: Summary safe motherhood scale-up costs

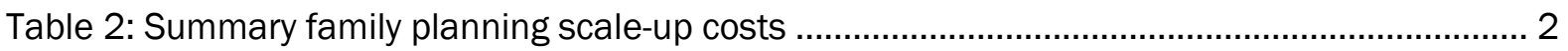

Table 3: Estimated health expenditure in Kenya 2013-2015 .................................................... 3

Table 4: Summary safe motherhood scale-up costs with increased reimbursement rates ............ 4

Table 5: Summary family planning scale-up costs with increased reimbursement rates................ 4

Table 6: Infant and maternal mortality data (KDHS 2008/09) …................................................ 5

Table 7: Contraceptive prevalence and fertility data (KDHS 2008/09) .......................................... 6

Table 8: Health expenditure in Kenya 2009/10 (NHA 2008/09) ................................................... 6

Table 9: Design of reproductive health OBA program in Kenya (2005-2012)................................ 8

Table 10: Estimate of number of deliveries (Source: U.S. Census Bureau, 2011; KDHS 2008/09)

Table 11: Unit costs and proportion calculations (Source: PwC claims data 2012) ..................... 14

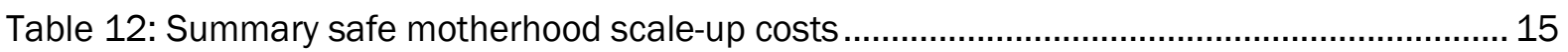

Table 13: Forecast of total number of women or reproductive age and the number of women of

reproductive age in the bottom two quintiles of the population .......................................... 16

Table 14: Target population(s) for scale-up of FP services .......................................................... 17

Table 15: Unit costs of FP services provided under the OBA voucher …...................................... 18

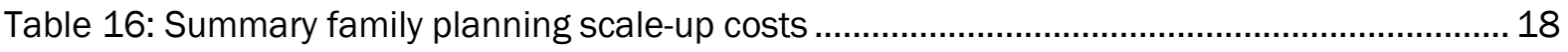

Table 17: Total cost of scale-up for three coverage targets across three years............................. 19

Table 18: Total cost of scale-up for three coverage targets across three years with increased

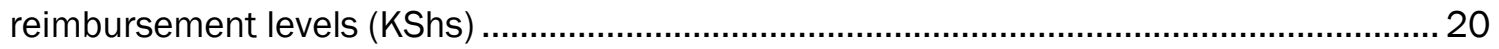

Table 19: Total cost of scale-up for three coverage targets across three years with increased reimbursement levels (US\$) 


\section{GLOSSARY}

FBO Faith-based organisation

FP Family planning

GBVR Gender-based violence recovery

IMR Infant mortality rate

KDHS Kenya Demographic and Health Survey

KfW German Development Bank

KNBS Kenya National Bureau of Statistics

MDG Millennium Development Goals

MMR Maternal mortality rate

MoPHS Ministry of Public Health and Sanitation (2008-2013)

$\mathrm{MOH} \quad$ Ministry of Health (split into two Ministries during Grand Coalition)

NCAPD National Coordinating Agency for Population and Development

NHA National health accounts

NHSSP National Health Sector Strategic Plan

NMR Neonatal mortality rate

NRHS National Reproductive Health Strategy

OBA Output-based aid

PwC PricewaterhouseCoopers

SMH Safe motherhood

TFR Total fertility rate

VMA Voucher management agency

WRA Women of reproductive age 


\section{EXECUTIVE SUMMARY}

Despite an international commitment to improving maternal health through the Millennium Development Goals (Goal 5: Improve maternal health), the trends in Kenya have not been in a positive direction. The 2008-09 Kenya Demographic and Health Survey found that there was approximately the same number of women dying of pregnancy and childbirth related causes 2004-2009 as in 1998-2003, namely 488 deaths versus 412 deaths per 100,000 live births. This is a matter of great concern, as these deaths arise from well-known preventable causes.

The Output Based Aid (OBA) program commenced in Kenya in 2005 with the first vouchers issued in June 2006 and has shown promising results. This voucher scheme is co-funded by the German Development Bank (KfW) and the Kenyan government and offers three different services to poor clients: a safe motherhood package of antenatal services and attended delivery by qualified health workers, long-term family planning methods, and gender-based violence recovery (GBVR) services at accredited facilities.

The estimates for scaling up the OBA program by applying past trends to projected data, adjusting for inflation and exchange rates and with some rounding differences, are as follows for the period 2013 to 2015 under three coverage scenarios:

TABLE 1: Summary safe motherhood scale-up costs

\begin{tabular}{|l|r|r|r|r|r|r|r|r|r|}
\hline & \multicolumn{3}{|c|}{$30 \%$ coverage } & \multicolumn{3}{c|}{$50 \%$ coverage } & \multicolumn{3}{c|}{$70 \%$ coverage } \\
\hline KSh millions: & 2013 & 2014 & 2015 & 2013 & 2014 & 2015 & 2013 & 2014 & 2015 \\
\hline $\begin{array}{l}\text { Reimbursement } \\
\text { costs }\end{array}$ & 1,083 & 1,184 & 1,220 & 1,805 & 1,974 & 2,034 & 2,527 & 2,763 & 2,848 \\
\hline Admin costs & 238 & 209 & 166 & 396 & 348 & 277 & 555 & 488 & 388 \\
\hline TOTAL cosTS & 1,321 & 1,393 & 1,387 & 2,201 & 2,322 & 2,312 & 3,081 & 3,251 & 3,236 \\
\hline US\$ millions: & & & & & & & & & \\
\hline $\begin{array}{l}\text { Reimbursement } \\
\text { costs }\end{array}$ & 12 & 14 & 14 & 21 & 23 & 23 & 29 & 32 & 33 \\
\hline Admin costs & 3 & 2 & 2 & 4 & 4 & 3 & 6 & 6 & 4 \\
\hline TOTAL COSTS & 15 & 16 & 16 & 25 & 27 & 27 & 35 & 38 & 37 \\
\hline
\end{tabular}

TABLE 2: Summary family planning scale-up costs

\begin{tabular}{|l|r|r|r|r|r|r|r|r|r|}
\hline & \multicolumn{3}{|c|}{$30 \%$ coverage } & \multicolumn{3}{|c|}{$50 \%$ coverage } & \multicolumn{3}{c|}{$70 \%$ coverage } \\
\hline KSh millions: & 2013 & 2014 & 2015 & 2013 & 2014 & 2015 & 2013 & 2014 & 2015 \\
\hline $\begin{array}{l}\text { Reimbursement } \\
\text { costs }\end{array}$ & 582 & 645 & 733 & 970 & 1,076 & 1,222 & 1,357 & 1,506 & 1,711 \\
\hline Admin costs & 128 & 114 & 100 & 213 & 190 & 167 & 298 & 266 & 233 \\
\hline TOTAL COSTS & 709 & 759 & 833 & 1,182 & 1,265 & 1,389 & 1,655 & 1,771 & 1,945 \\
\hline US\$ millions: & & & & & & & & & \\
\hline $\begin{array}{l}\text { Reimbursement } \\
\text { costs }\end{array}$ & 7 & 8 & 8 & 11 & 13 & 14 & 16 & 17 & 20 \\
\hline Admin costs & 1 & 1 & 1 & 2 & 2 & 2 & 3 & 3 & 3 \\
\hline TOTAL COSTS & 8 & 9 & 10 & 14 & 15 & 16 & 19 & 20 & 22 \\
\hline
\end{tabular}


The total government health budget for 2011/12 presented in Kenya National Bureau of Statistics' Classification of Expenditure by Purpose is KSh 69.13 billion. Using this and applying 2009/10 National Health Account (NHA) 1 trends with adjustments for inflation, the estimated potential Total Health Expenditure (THE) and reproductive health expenditure between 2013 and 2015 is as follows:

TABLE 3: Estimated health expenditure in Kenya, 2013-2015

\begin{tabular}{|l|r|r|r|}
\hline Estimated (KSHs billions) & 2013 & 2014 & 2015 \\
\hline Total health expenditure (THE) & 273.42 & 295.76 & 327.11 \\
\hline Government health expenditure & 78.75 & 85.18 & 94.21 \\
\hline Reproductive health expenditure & 38.01 & 41.11 & 45.47 \\
\hline Government reproductive health expenditure & 15.20 & 16.44 & 18.19 \\
\hline
\end{tabular}

In the NHA 2009/10, reproductive health expenditure as a percentage of THE was $13.9 \%$ and this percentage has been applied to 2013 to 2015. NHA 2009/10 public sector proportions of THE (28.8\%) and reproductive health (40\%) have been applied to 2012 KNBS estimates and adjustments made for inflation to estimate government health expenditure between 2013 and 2015.

The figures show that, for example, in 2013 with 50\% coverage, the total costs of KSh 3,383 million (safe motherhood, family planning and administrative costs) would comprise:

- $1.2 \%$ of estimated THE

- $4.3 \%$ of estimated government health expenditure

- $8.9 \%$ of estimated reproductive health expenditure

- $22.3 \%$ of estimated government reproductive health expenditure

The PwC Phase II evaluation report noted that reimbursement levels may be too low and there is a threat that service providers may withdraw. Program costs for 2013 would range from KSh 2.1 billion (30\% coverage of poor) to KSh 4.9 billion (70\% coverage of poor) if reimbursement rates were increased by $5 \%$ above forecast inflation.

\footnotetext{
1 Jointly issued by Ministry of Public Health and Ministry of Medical Services with financial support from USAID, WHO and World Bank
} 
TABLE 4: Summary safe motherhood scale-up costs with increased reimbursement rates

\begin{tabular}{|c|c|c|c|c|c|c|c|c|c|}
\hline KSh millions: & 2013 & 2014 & 2015 & 2013 & 2014 & 2015 & 2013 & 2014 & 2015 \\
\hline $\begin{array}{l}\text { Reimbursement } \\
\text { costs }\end{array}$ & 1,137 & 1,243 & 1,282 & 1,895 & 2,072 & 2,136 & 2,653 & 2,901 & 2,990 \\
\hline Admin costs & 250 & 219 & 175 & 416 & 366 & 291 & 582 & 512 & 408 \\
\hline TOTAL COSTS & 1,387 & 1,463 & 1,456 & 2,311 & 2,438 & 2,427 & 3,235 & 3,413 & 3,398 \\
\hline \multicolumn{10}{|l|}{ US\$ millions: } \\
\hline $\begin{array}{l}\text { Reimbursement } \\
\text { costs }\end{array}$ & 13 & 14 & 15 & 22 & 24 & 25 & 30 & 34 & 34 \\
\hline Admin costs & 3 & 3 & 2 & 5 & 4 & 3 & 7 & 6 & 5 \\
\hline TOTAL COSTS & 16 & 17 & 17 & 27 & 28 & 28 & 37 & 40 & 39 \\
\hline
\end{tabular}

TABLE 5: Summary family planning scale-up costs with increased reimbursement rates

\begin{tabular}{|l|r|r|r|r|r|r|r|r|r|}
\hline & \multicolumn{3}{|c|}{$30 \%$ coverage } & \multicolumn{3}{|c|}{$50 \%$ coverage } & \multicolumn{3}{|c|}{$70 \%$ coverage } \\
\hline KSh millions: & 2013 & 2014 & 2015 & 2013 & 2014 & 2015 & 2013 & 2014 & 2015 \\
\hline $\begin{array}{l}\text { Reimbursement } \\
\text { costs }\end{array}$ & 611 & 678 & 770 & 1,018 & 1,129 & 1,283 & 1,425 & 1,581 & 1,797 \\
\hline Admin costs & 134 & 120 & 105 & 223 & 199 & 175 & 313 & 279 & 245 \\
\hline TOTAL COSTS & 745 & 798 & 875 & 1,241 & 1,328 & 1,458 & 1,738 & 1,860 & 2,042 \\
\hline US\$ millions: & & & & & & & & 15 & 18 \\
\hline $\begin{array}{l}\text { Reimbursement } \\
\text { costs }\end{array}$ & 7 & 8 & 9 & 12 & 13 & 15 & 16 & 21 \\
\hline Admin costs & 2 & 1 & 1 & 2 & 2 & 2 & 4 & 3 & 3 \\
\hline TOTAL COSTS & 9 & 9 & 10 & 14 & 15 & 17 & 20 & 22 & 24 \\
\hline
\end{tabular}

The change in reimbursement rates from the combined increase in $5 \%$ in reimbursement rates and increase in inflation leads to an overall increase in $20 \%$ between the reimbursement rates from 2012 to 2013. However, the safe motherhood, family planning and administration costs increase by $5 \%$ between the estimates before and after the reimbursement level increases.

Programmatic changes may impact the costs. For example, the introduction of transport reimbursements to patients could improve access to the OBA services but would increase costs due to transport expenses and a greater number of distributed vouchers being used. It is difficult to estimate how much and on what basis these reimbursements may be made so they have not been factored in the scale up cost estimates. However, if transport is added, then the above scenarios would again have higher programmatic costs. Scaling up nationally with many new geographical areas may also alter the logistical administration of the OBA program and impact on the administrative costs also. Therefore, using PwC administrative cost trends where administrative costs as a proportion of total costs were higher at the beginning of each Phase, the calculations have been assumed to be higher in 2013 and gradually decreasing in 2015 as a proportion of total costs. 


\section{CONTEXT: KENYA'S DEMOGRAPHIC INDICATORS AND HEALTH SPENDING}

According to the Population Reference Bureau (2012), Kenya's population is approximately 43 million and is growing rapidly at the rate of $2.7 \%$ per annum. With fewer than 2 years left for achieving the Millennium Development Goals (MDG), Kenya has renewed its effort to meet goals 4 and 5 relating to maternal and child health. The last Kenya Demographic and Health Survey (KDHS) 2008/09 shows the following trends related to infant, neonatal and maternal mortality in the country (Table 6).

TABLE 6: Infant and maternal mortality data (KDHS 2008/09)

\begin{tabular}{|l|l|l|}
\hline Indicator & 2003 & $2008 / 09$ \\
\hline $\begin{array}{l}\text { Infant mortality rate (IMR) } \\
/ 1000 \text { live births }\end{array}$ & 77 & 52 \\
\hline $\begin{array}{l}\text { Under-5 mortality rate } \\
/ 1000 \text { live births }\end{array}$ & 115 & 74 \\
\hline $\begin{array}{l}\text { Neonatal mortality rate (NMR) } \\
/ 1000 \text { live births }\end{array}$ & 33 & 31 \\
\hline $\begin{array}{l}\text { Maternal mortality rate (MMR) } \\
/ 100,000 \text { live births }\end{array}$ & 414 & 488 \\
\hline
\end{tabular}

As can be seen from the table above, Kenya has made significant progress in tackling infant and under-5 mortality, but there has been only a marginal improvement in its neonatal mortality figures. The IMR MDG target for 2012 was 37 deaths/1000 live births and for MMR was an ambitious 147 deaths/100,000 live births. However, since 2003, the maternal mortality rate has largely remained unchanged and is still a major challenge.

In Kenya, the challenges posed by weak health systems are compounded by a vast gap in the provision of quality maternal and child health services between the economically better-off and the poor. Skilled attendance at birth is only $43.8 \%$ (KHDS 2008/09) and is a crucial contributing factor to the high levels of neonatal and maternal mortality. In rural areas the births attended by skilled health providers are as low as $36.8 \%$. Among the bottom two quintiles, only $24 \%$ of women deliver in a facility.

Kenya's high population growth rate needs to be analysed through the lens of both levels of contraceptive prevalence and fertility trends. KDHS (2008/09) reports the following data (Table 7): 
TABLE 7: Contraceptive prevalence and fertility data (KDHS 2008/09)

\begin{tabular}{|l|l|}
\hline Indicator & $2008 / 09$ \\
\hline $\begin{array}{l}\text { Total fertility rate (TFR) } \\
\text { Avg. number of children a woman would have through her entire reproductive } \\
\text { period }\end{array}$ & 4.60 \\
\hline $\begin{array}{l}\text { Contraceptive prevalence } \\
\text { Proportion of all women of reproductive age (WRA) who are using (or whose } \\
\text { partner is using) a contraceptive method at a given point in time }\end{array}$ & $44 \%$ \\
\hline $\begin{array}{l}\text { Percentage of all WRA using: } \\
\text { Sterilisation as a contraceptive method } \\
\text { IUDs as a contraceptive method } \\
\text { Implants as a contraceptive method }\end{array}$ & $3.2 \%$ \\
\hline $\begin{array}{l}\text { FP unmet need: } \\
\text { Married women }\end{array}$ & $4.0 \%$ \\
\hline
\end{tabular}

The low uptake levels of long-term contraception methods, especially in the poorest two quintiles of the population, remain a challenge. The total fertility rate in Kenya was as high as 6 births in a woman's lifetime in the 1950s, falling to about 5 births in the mid-1990s and then in the 2000s failed to drop further with significant disparities by economic status as poor women on average had a significantly higher number of children. These figures indicate that family planning programs have to take into account the barriers to access faced by poor women.

In terms of national spending on health, Kenya's National Health Accounts 2009/10 provide the following information related to Total Health Expenditure (THE) which comprises both public and private sectors' health expenditures:

TABLE 8: Health expenditure in Kenya 2009/10 (NHA 2008/09)

\begin{tabular}{|l|r|}
\hline Key results & $2009 / 10$ \\
\hline THE in absolute values & $\begin{array}{r}\text { KSh } 122.9 \text { billion } \\
\text { (US\$1,620 million) }\end{array}$ \\
\hline THE per capita & KSh 3,203 \\
& US\$ 42) \\
\hline Government health expenditure & KSh 35.4 billion \\
\hline Government health expenditure as \% of total government expenditure & $4.6 \%$ \\
\hline Total reproductive health expenditure & KSh 17.1 billion \\
& (US\$225 million) \\
\hline Reproductive health expenditure as \% of THE & $13.9 \%$ \\
\hline Reproductive health financing sources: & $40 \%$ \\
Public & $38 \%$ \\
Private & $22 \%$ \\
\hline Donors & KSh 6.8 billion \\
\hline
\end{tabular}

GIZ in its Health budget analysis report 2011 noted that the budget allocation to the health sector - Ministry of Medical Services (MoMS) and Ministry of Public Health and Sanitation 
(MoPHS) - for FY 2010/11 accumulated to a total of KSh 41.5 billion of government resources which represents $6.5 \%$ of the total estimated government budget and $1.5 \%$ of the Gross Domestic Product (GDP). This amounts to KSh 1,064 (13.1 USD) per capita.

\section{OUTPUT-BASED AID (OBA) APPROACH IN KENYA}

\subsection{Context}

The Second National Health Sector Strategic Plan in Kenya or NHSSP II (2005-2010) outlined reproductive health as one of the priority health packages. The core reproductive health services in NHSSP II include: family planning, unmet need for contraception, safe motherhood and child survival, management of STDS/HIV/AIDS, promotion of adolescent and youth health, management of infertility, gender issues \& reproductive rights, and other issues including chronic illnesses and cancers of the reproductive system. The plan came to an end in June 2012 and preparations are underway to finalise the next plan: Kenya Health Sector Strategic Plan-KHSSP (2012-2017).

The government in partnership with external donors has recognised that despite significant investment in the supply side of the health sector, the uptake of services has remained low (for example, institutional deliveries constitute only $43 \%$ of all deliveries). The Kenya Vision 2030 is a government strategy that aims to transform Kenya into a middle-income country by 2030 , advocating innovative output-based financing models for the health sector and the development of a national health insurance scheme. The OBA approach is highlighted as one of two priorities in Vision 2030 and has already helped create demand for health services by motivating providers to cater for the health needs of the poorest and most vulnerable sections of the population.

The goal of the National Reproductive Health Strategy (NRHS) 2009 to 2015 is to facilitate the operationalization of the National Reproductive Health Policy, launched in 2007, through a multisectoral approach. The goal of the Policy is to enhance the reproductive health status of all Kenyans by increasing equitable access to reproductive health services; improving quality, efficiency and effectiveness of service delivery at all levels; and improving responsiveness to the client needs. The main objective under the maternal and neonatal health component is to reduce rates of maternal, perinatal and neonatal morbidity and mortality in Kenya. The expected output of its implementation strategies is increased availability, accessibility, acceptability, and utilisation of skilled attendance during pregnancy, childbirth and the postpartum period at all levels of the health care delivery system. One of the strategies to address this is increasing 
service availability by scaling up OBA voucher schemes ${ }^{2}$. Overall, the reproductive health OBA program fits well under this strategy. It not only provides poor women access to reproductive health services, but also enhances the capacity and quality of services of the service providers by reimbursing service costs and allowing facilities to invest in expanding capacity.

\subsection{Design of Voucher Scheme}

A pilot Reproductive Health OBA program has been in operation in Kenya since 2005 with the first vouchers issued in June 2006 and has shown promising results. This voucher scheme is cofunded by the German Development Bank ( $\mathrm{KfW}$ ) and the Kenyan government and offers three different services to poor clients: a safe motherhood package of antenatal services and attended delivery by qualified health workers, long-term family planning methods, and gender-based violence recovery (GBVR) services at accredited facilities. These vouchers are priced at a heavily discounted rate of KSh 200 (\$2.70) for the safe motherhood services and KSh 100 (\$1.35) for family planning services and no cost for the GBVR services. The table below outlines in detail the design of this scheme (Table 9).

TABLE 9: Design of reproductive health OBA program in Kenya (2005-2012)

\begin{tabular}{|l|l|}
\hline Feature & Observation \\
\hline Funding & GoK/KFW \\
\hline Phases & Phase 1: October 2005-October 2008 \\
& $\begin{array}{l}\text { Phase 2: November 2008-October 2011 } \\
\text { Phase 3: November 2011-October 2014 }\end{array}$ \\
\hline Government body & $\begin{array}{l}\text { Phase 1: Ministry of Planning, National Agency Coordinating Agency for } \\
\text { Population and Development (NCAPD) } \\
\text { Phase 2 \& 3: Ministry of Public Health and Sanitation, Department of } \\
\text { Economic Policy and Planning }\end{array}$ \\
\hline Project areas & $\begin{array}{l}\text { Phase 1: Nairobi (Korogocho, Viwandani), Kiambu, Kisumu, Kitui districts) } \\
\text { Phase 2 Addition of Kaloleni and Kilifi districts }\end{array}$ \\
\hline Goune 3: Nairobi (Korogocho, Viwandani), Kiambu, Kisumu, Kitui, and Kilifi \\
\hline counties in 2014. \\
\hline Steering committee \\
\hline
\end{tabular}

\footnotetext{
2 Section 2.3.1 Maternal and Neonatal Health, NRHS, STRATEGY 3: Increase availability of Integrated
} Maternal and Neonatal Health Services, at all Levels 


\begin{tabular}{|c|c|}
\hline $\begin{array}{l}\text { Quality of services } \\
\text { monitoring }\end{array}$ & $\begin{array}{l}\text { Phase 1: NHIF } \\
\text { Phase 2: MOH technical committee } \\
\text { Phase 3: Contracted accreditation and quality assurance agency }\end{array}$ \\
\hline Quality improvement & $\begin{array}{l}\text { Checked at accreditation and reinforced where there is competition } \\
\text { between providers }\end{array}$ \\
\hline Targeting approach & $\begin{array}{l}\text { Poverty grading tool, originally developed by MSI as a participatory } \\
\text { mechanism, with indicators unique to each district or county }\end{array}$ \\
\hline Referral & Covered \\
\hline $\begin{array}{l}\text { Cost of vouchers to } \\
\text { clients }\end{array}$ & $\begin{array}{l}\text { Ksh. } 200 \text { for SMH services } \\
\text { Ksh.100 for FP services } \\
\text { Free for GBV }\end{array}$ \\
\hline $\begin{array}{l}\text { Reimbursement } \\
\text { mechanism }\end{array}$ & $\begin{array}{l}\text { Reimbursement based on fixed rates per service type plus allowances for } \\
\text { treatment of complications }\end{array}$ \\
\hline Distributors & Contracted distributors (CBO, FBO, NGO, and individuals) \\
\hline Providers & $\begin{array}{l}\text { Private, FBO, NGO, Public levels } 3,4,5^{3} \\
\text { Phase 1: } 54 \text { facilities } \\
\text { Phase 2: } 83 \text { facilities } \\
\text { Phase 3: } 150-200 \text { facilities }\end{array}$ \\
\hline Clients & Poor pregnant women, GBV victims, poor families \\
\hline
\end{tabular}

This scheme currently caters to a population of over 3 million in the five above-mentioned pilot districts with an additional two districts added in Phase II. It is being implemented in three phases: Phase I (Oct 2005- Oct 2008) with a budget of $€ 6.5$ million; Phase II (Nov 2008- Oct 2011) budgeted at $€ 10.00$ million (KfW) and $€ 0.3$ million (MoPHS); and Phase III (Nov 2011-Oct 2014) budgeted at $€ 13.7$ million ( $\mathrm{KfW}$ ) and $€ 1.5$ million $(\mathrm{MoH})$.

In Phase II, PwC reported that 83 facilities had been contracted as voucher service providers. A total of 166,064 Safe Motherhood vouchers and 67,087 Family planning vouchers had been sold in Phase I and Phase II. Total deliveries in Phase I and Phase II were 119,795 and a total 39,460 of family planning services had been provided in Phase I and Phase II. In its Phase I report (Oct 2008), PwC notes that lower utilization of sold safe motherhood vouchers is due to several factors such as large distances in rural areas, poor communication and lack of transport and household level dynamics. Family planning voucher utilisation is lower than sold vouchers due to contraceptive stock outs and household level dynamics regarding seeking family planning, particularly when women consult their partners.

3 This is based on health facility levels defined before the new Constitution. 
Total project costs reported in Phase II were KShs 796,360,726, 15\% of which related to operational costs. Total Safe Motherhood reimbursements at the end of Phase II were KShs $507,327,518$ and family planning reimbursements were KShs 52,481,878.

\subsection{Evaluation of Voucher Scheme}

There have been several internal and external evaluations of the voucher program. The first was done internally by PWC. Population Council, IPE Global and $\mathrm{KfW}^{4}$ have carried out external evaluations to describe operational issues and measure the effect of the program on clients, providers and the general population.

A review of the scheme conducted by PwC in 2008 found that the voucher sales and utilization rates of the Safe Motherhood vouchers exceeded targets. The high uptake of the SMH voucher suggests that the program is popular and can significantly reduce economic barriers for poor pregnant women who previously did not deliver at facilities. PwC found that in Phase II, 80.25\% of the sales forecast was achieved, attributed to disruption and resulting loss of momentum between Phase I and II. PwC (2011) reported that during Phase I of the project, there was slow uptake of family planning services across the project sites. In Phase II, the family planning services picked up significantly with community based outreach conducted by trained healthcare workers having a positive impact on family planning service uptake (PwC 2011).

A key recommendation made by PwC in its End of Phase II report was to expand the program further in other counties to spread OBA benefits to more Kenyans and to help shape a national healthcare financing scheme. Although the report does not specify which lessons, key learning that could result from expanding the program nationally could include: effective coordination and management of a national healthcare financing scheme with multiple stakeholders; logistical implementation differences between counties; urban versus rural comparisons; and variations in attitudes between different communities and between different generations. The report also recommends reviewing reimbursement levels to facilities as some private sector and FBO facilities have opted out of the OBA program due to low reimbursement levels. This scenario is further explored in Section 4.

In 2009, the Population Council began an external evaluation and conducted a baseline assessment of the reproductive health voucher program, measuring both program management and program outcomes (Population Council, 2011). The baseline assessment found several positive impacts of the program including:

- improved capital investment at the facility level;

- high levels of satisfaction among voucher clients regarding service provision;

\footnotetext{
${ }^{4}$ Analysis of Kenya OBA programme data - phase 2, Anna Gorter (June 2012).
} 
- reduced levels of out-of-pocket expenditures for voucher clients;

- improved level of knowledge regarding potential complications that could arise during pregnancy and child birth;

- higher use of reproductive health services among poor voucher holders than non-voucher holders;

- reduced socio-economic inequities in service utilisation among voucher clients; and

- a perceived decline in maternal deaths in the community as a result of the safe motherhood voucher.

The IPE Global Private Limited end of Phase II evaluation report 5 found that Phase II was successful having impacted positively on the lives of the intended beneficiaries. By the end of Phase II, an estimated 234,886 WRA or $24 \%$ of the target population in the five regions were reached. This figure represented $27 \%$ of the estimated 857,993 WRAs at the start of Phase II. The success of Phase II was largely due to the relevance of the project design set up in Phase I and continuing in Phase II, which was an innovative and appropriate approach to health service delivery (IPE Global 2012). The greatest challenge to the project IPE Global reported in Phase II was in the area of efficiency in some aspects of management, which affected the timely use of human, financial and physical resources.

The KfW End of Phase II report analyses the Phase 1 and Phase 2 data. The analysis shows that compared to Phase 1, many more FP vouchers were used during Phase 2. Facilities introduced FP outreach activities during Phase 2 and women became more familiar with long term methods. The report noted that word-of-mouth advertising probably played an important role. SMH increases were observed as well between Phases 1 and 2 . The report notes that the SMH increase seen between Phases 1 and 2 was not the result of the expansion to Kilifi, but due to an increased distribution and utilisation of SMH vouchers in the existing areas: the increase in use of SMH vouchers is most likely the result of increasing familiarity of the program. The report further analyses the total number of voucher service providers and WRA in the areas served under this program. It found that the number of VSPs in Kilifi needs to be increased and Kitui and Kisumu may benefit from contracting more facilities. When comparing data by facility type (NGO, FBO, private or public), the analysis in the report shows that there is a huge difference between the percentages of complications between facilities: ranging from $0 \%$ to $60 \%$, with high frequencies of complications, not only in the private and NGO sector but also in the FBO sector, and in a few public facilities. This indicates that the problem is related to health facilities trying to maximise their benefits. Contracts have had to be terminated in the private and NGO sectors because of fraud.

\footnotetext{
${ }^{5}$ End of Phase II Evaluation and Phase III Baseline Survey of the Reproductive Health - Output-Based Approach (OBA) Project (December 2012)
} 


\section{Cost of Scaling Up}

Results show that the pilot OBA scheme in Kenya has not only enabled poor women to access health services that were initially out of their financial reach, but is likely to have had a direct positive impact on maternal mortality (Population Council, 2011). With these encouraging results, the OBA program can become a decisive tool in Kenya's crusade against maternal mortality if scaled up appropriately.

Scaling up of such a program must go hand in hand with the establishment of an appropriate institutional set up. The IPE Global End Of Phase II Evaluation \& Phase III Baseline Survey (December 2012) report recommends realigning/reassigning new PMU staff to fit the RH-OBA project design. This will be even more necessary should the project scale up. It is assumed that the administrative costs will be higher in 2013 as a result of these changes (see section 4.4) and decrease as a proportion of total costs over the projected period.

The baseline evaluation paper (Population Council, 2011), also found that there was a need to improve coverage in remote areas. Even though targeting in this OBA scheme was pro-poor, other aspects of distribution could be improved. For instance, there was a need for greater community sensitization regarding the use of long-term family planning methods. A need for a transport subsidy also emerged, and all these issues may need to be considered as the program is scaled up. However, this scale up report does not include programmatic changes such as transport subsidies as it is difficult at this stage to know the criteria for implementing such a subsidy in a scaled-up program, and therefore, the financial outlay required to implement it.

The estimated costs of scaling up both safe motherhood and family planning services are elucidated in the sections below. The scale-up cost estimation considers the cost of scale-up over three years - 2013, 2014 and 2015. It also gives estimates using three coverage targets- 30\% (low), 50\% (medium) and 70\% (high) of all deliveries attributed to the poor; and meeting 30\%, $50 \%$ and $70 \%$ of the unmet need for long-term contraception in the poor as identified using the KDHS wealth index. KDHS developed ${ }^{6}$ a wealth index as a proxy for standard of living using characteristics ${ }^{7}$ related to a household's socio-economic status. The ranking of individuals was then divided into five wealth quintiles. The bottom two quintiles have been used as a basis for identifying the poor for the scale up calculations. The current OBA scheme uses a poverty grading tool to identify the poor and although the tool uses some similar criteria, it has not been validated and may not correspond $100 \%$ to the population in the bottom two quintiles, as measured in the KDHS reports.

\footnotetext{
${ }^{6}$ Section 2.6 KDHS 2008/09

${ }^{7}$ Characteristics included ownership of consumer goods; dwelling conditions; drinking water source; toilet facilities among others related to socio-economic status.
} 


\subsection{Assumptions}

A forecasting exercise rests on various assumptions. The assumptions in this paper are divided into three broad categories:

- Demographic

- Number of deliveries

- Number of deliveries attributed to the poor

- Number of expected home based deliveries amongst the poor

- Economic

- Inflation rates

- USD-KES exchange rates

- Program-related

- Change in administrative costs

- Change in reimbursement rates

- Poverty identification by the program is comparable to national poverty scales

U.S. Census Bureau data were used to estimate the number of annual deliveries from 20132015. Trends using the KDHS 2008/09 data (Annex C) were applied to this to determine potential home based deliveries amongst the poor to define the unmet need attributed to the poor. The unmet need for family planning and the number of deliveries attributed to the poor were calculated based on figures from the KDHS (2008/09).

Forecast data from TradingEconomics was used for exchange rates and inflation rates for 2013 to 2015 .

\subsection{Administrative Costs}

In the first phase, the PwC (2008) review found that till 2008, the administrative ${ }^{8}$ costs of $^{2}$ running the voucher program had been $21 \%$ while the direct benefits to the clients were about 79\%. In Phase two, PwC (2011) report states that 15\% of the total costs are administrative. These specifically ranged from $18 \%$ in $2008 / 09,15 \%$ in $2009 / 10$ to $12 \%$ in $2010 / 11$.

Proportionate calculations for program management costs may be made using the PwC reported costs in Phase II. Costs may be higher initially in 2013 and 2014 as the administration costs of scaling up may be higher, with a reduction from 2015. On this basis, $18 \%$ of administrative costs may be earmarked for 2013, 15\% for 2014, and $12 \%$ for 2015 .

\footnotetext{
8 In Phases I \& II, OBA administrative costs included: accreditation; impact monitoring (quality assurance); training; marketing \& distribution; process monitoring; advocacy; communications/public relations; distribution sensitization; distributors' commission; VMA costs; and bank charges.
} 
These rates have been applied in sections 3.3 to 3.5 to show the administrative cost of the safe motherhood and family planning programmes.

\subsection{Safe Motherhood Services}

For the purpose of forecasting, U.S. Census Bureau data ${ }^{9}$ estimate that the number of births in Kenya in 2013 will be 1,325,000, in 2014 will be 1,272,000 and in 2015 will be 1,212,000. KDHS 2008/09 reported that the lowest quintile delivered $24.7 \%$ of babies in Kenya and nearly $80.9 \%$ of those births were at home, while the second lowest quintile produced $20.3 \%$ of all births with $68.3 \%$ of these deliveries at home (Annex $\mathrm{C}$ ). Based on those figures, the following delivery estimates were calculated for each year:

TABLE 10: Estimate of number of deliveries (Source: US Census Bureau, 2011; KDHS 2008/09)

\begin{tabular}{|l|r|r|r|}
\hline & 2013 & 2014 & 2015 \\
\hline No. of deliveries & $1,325,000$ & $1,272,000$ & $1,212,000$ \\
\hline No. of home based deliveries (lowest quintile) & 264,684 & 254,097 & 242,111 \\
\hline No. of home based deliveries (second quintile) & 184,026 & 176,665 & 168,332 \\
\hline TOTAL PROJECTED HOME-BASED DELIVERIES & 448,710 & 430,762 & 410,443 \\
AMONGST THE POOR & & & \\
\hline Low target (30\%) & 134,613 & 129,229 & 123,133 \\
\hline Medium target (50\%) & 224,355 & 215,381 & 205,221 \\
\hline High target (70\%) & 314,097 & 301,533 & 287,310 \\
\hline
\end{tabular}

The table below outlines the unit cost of each of these services and the proportion of total numbers based on PwC 2012 claims data (Table 11). ${ }^{10}$ The cost data has been updated for the projected years by the projected inflation rates for those years. The table below summarises the results.

TABLE 11: Unit costs and proportion calculations (Source: PwC claims data 2012)

\begin{tabular}{|l|c|c|c|c|}
\hline Service & $\begin{array}{c}\text { Reimbursement } \\
\text { rates } \\
2013(\text { KSh) }\end{array}$ & $\begin{array}{c}\text { Reimbursement } \\
\text { rates } \\
2014(\mathrm{KSh})\end{array}$ & $\begin{array}{c}\text { Reimbursement } \\
\text { rates } \\
\mathbf{2 0 1 5}(\mathrm{KSh})\end{array}$ & $\begin{array}{c}\text { Percentage of } \\
\text { deliveries }\end{array}$ \\
\hline ANC & 1,113 & 1,204 & 1,331 & $99 \%$ \\
\hline Normal delivery & 5,225 & 5,652 & 6,251 & $89 \%$ \\
\hline Caesarean section & 23,864 & 25,814 & 28,550 & $11 \%$ \\
\hline Complications & 3,276 & 3,544 & 3,919 & $24 \%$ \\
\hline
\end{tabular}

\footnotetext{
9 http://www.census.gov/population/international/data/idb/country.php

10 Note that the calculations are based on vouchers that will be utilized as opposed to the number sold. As with the current OBA program, vouchers sold are likely to be higher than those utilized.
} 
Unfortunately, poor women do not seem to make full use of their ANC entitlement, with most women only attending one ANC visit. Reasons cited include lack of transport and difficulty to travel as the pregnancy advances. It has been assumed that this trend will not change in the medium term.

From the data in the tables above, the cost for the three coverage targets were computed. The results were translated into US\$ using TradingEconomics exchange rate forecast data as follows:

2013: $\$ 1=86.94 \mathrm{KSh}$

2014: $\$ 1=86.02 \mathrm{KSh}$

2015: $\$ 1=86.69 \mathrm{KSh}$

The calculations yield the following costs (in millions) including the administrative costs:

TABLE 12: Summary safe motherhood scale-up costs

\begin{tabular}{|l|r|r|r|r|r|r|r|r|r|}
\hline & \multicolumn{3}{|c|}{$30 \%$ coverage } & \multicolumn{3}{c|}{$50 \%$ coverage } & \multicolumn{3}{|c|}{$70 \%$ coverage } \\
\hline KSh millions: & 2013 & 2014 & 2015 & 2013 & 2014 & 2015 & 2013 & 2014 & 2015 \\
\hline $\begin{array}{l}\text { Reimbursement } \\
\text { costs }\end{array}$ & 1,083 & 1,184 & 1,220 & 1,805 & 1,974 & 2,034 & 2,527 & 2,763 & 2,848 \\
\hline Admin costs & 238 & 209 & 166 & 396 & 348 & 277 & 555 & 488 & 388 \\
\hline TOTAL COSTS & 1,321 & 1,393 & 1,387 & 2,201 & 2,322 & 2,312 & 3,081 & 3,251 & 3,236 \\
\hline US\$ millions: & & & & & & & & & \\
\hline $\begin{array}{l}\text { Reimbursement } \\
\text { costs }\end{array}$ & 12 & 14 & 14 & 21 & 23 & 23 & 29 & 32 & 33 \\
\hline Admin costs & 3 & 2 & 2 & 4 & 4 & 3 & 6 & 6 & 4 \\
\hline TOTAL COSTS & 15 & 16 & 16 & 25 & 27 & 27 & 35 & 38 & 37 \\
\hline
\end{tabular}

If US \$25 million (including administration costs) were available for the safe motherhood component in the OBA scheme in $2013,50 \%$ of the deliveries by women in the lowest two quintiles would be by skilled attendants at a health facility. This would double the current number of poor women receiving qualified maternity care.

The total government health budget in 2011/12 was KSh 69.13 billion (KNBS11). This represents $5.9 \%$ of the total government $2011 / 12$ budget estimate. If this figure is used and extrapolated with the NHA proportions (see section 2), reproductive health expenditure is estimated at KSh 38.01 billion in 2013 (see Annex D for calculations). Therefore, the safe motherhood component of that to achieve 50\% coverage would be $5.8 \%$ of total reproductive health expenditure (including the related administrative costs).

${ }^{11}$ Classification of Expenditure by Purpose www.knbs.or.ke/sectoral/Pfinance/Classification\%20of\%20Expenditure\%20by\%20Purpose.pdf 


\subsection{Family Planning Services}

US Census Data population projections have been used to determine the number of WRA in the 15 to 49 category in the table below.

TABLE 13: Forecast of total number of women or reproductive age and the number of women of reproductive age in the bottom two quintiles of the population

\begin{tabular}{|c|c|c|c|}
\hline & 2013 & 2014 & 2015 \\
\hline Total projected population ${ }^{\wedge}$ & $44,037,656$ & $45,010,056$ & $45,925,301$ \\
\hline Total projected WRA^ & $10,607,808$ & $10,877,750$ & $11,177,158$ \\
\hline Proportion of married women of WRA* & \multicolumn{3}{|c|}{$58.36 \%$} \\
\hline Married WRA & $6,190,819$ & $6,348,360$ & $6,523,097$ \\
\hline Married women lowest quintile - \%** & \multicolumn{3}{|c|}{$17.65 \%$} \\
\hline Married women second quintile - \%** & \multicolumn{3}{|c|}{$17.9 \%$} \\
\hline Poor married WRA lowest quintile & $1,092,941$ & $1,120,753$ & $1,151,602$ \\
\hline Poor married WRA second quintile & $1,109,272$ & $1,137,500$ & $1,168,810$ \\
\hline Unmet need in poor married WRA - lowest quintile $\%^{+}$ & \multicolumn{3}{|c|}{$38 \%$} \\
\hline $\begin{array}{l}\text { Unmet need in poor married WRA - second } \\
\text { quintile } \%^{+}\end{array}$ & \multicolumn{3}{|c|}{$32.5 \%$} \\
\hline Unmet need in poor married WRA - lowest quintile & 415,318 & 425,886 & 437,609 \\
\hline Unmet need in poor married WRA - second quintile & 360,513 & 369,688 & 379,863 \\
\hline Total number of poor, married WRA with unmet need & 775,831 & 795,574 & 817,472 \\
\hline Unmarried WRA & 4,416,989 & $4,529,390$ & $4,654,061$ \\
\hline Poor unmarried women $\%^{++}$ & \multicolumn{3}{|c|}{$17.79 \%$} \\
\hline Poor unmarried WRA & 785,611 & 805,603 & 827,777 \\
\hline Unmet need in poor unmarried WRA\& & \multicolumn{3}{|c|}{$4.42 \%$} \\
\hline Number of poor, unmarried women with unmet need & 34,693 & 35,575 & 36,555 \\
\hline Total number of poor WRA with an unmet need & 810,524 & 831,149 & 854,027 \\
\hline
\end{tabular}

$\wedge$ US Census Data

*Pg. 97, KDHS (2008/09) Table 7.3 Proportion of currently married women to all women

** Proportion of married women in each quintile to total married women

+ Pg 97, KDHS (2008/09) Table 7.3

${ }^{++}$Average of $\%$ of lowest two quintiles of married women

\& KDHS (2008/09) estimates that average unmet need among unmarried WRA is $3.2 \%$. Assuming unmet need in the bottom two quintiles of unmarried women is in the same proportion to the average unmet need as in married women, the figure has been adjusted

The unmet need 12 for contraception is fairly high in Kenya, with a quarter of women unable to meet their contraceptive needs (KDHS 2008/09). Among married women, the unmet need in the bottom two quintiles is an average of 35\%. Among unmarried women, the KDHS estimates an average unmet need of 3.2\%. Estimating (as detailed below the table) the unmet need in the

12 Unmet need: Proportion of women wanting to space or limit births among all women of reproductive age (15-49 years). Women who want to postpone their next birth for two or more years or who want to stop childbearing altogether but are not using a contraceptive method are said to have an unmet need for family planning. 
bottom two quintiles of unmarried women at $4.42 \%$, the total number of poor WRA with an unmet need for contraception in Kenya may be computed.

With this target population across three years, the FP component of the OBA program can be scaled up to meet $30 \%, 50 \%$ and $70 \%$ of the unmet need among poor Kenyan women (Table 14).

TABLE 14: Target population(s) for scale-up of FP services

\begin{tabular}{|l|r|r|r|}
\hline $\begin{array}{l}\text { Coverage target: Bottom } \\
\text { two quintiles: }\end{array}$ & 2013 & 2014 & 2015 \\
\hline Low $(30 \%)$ & 243,157 & 249,345 & 256,208 \\
\hline Medium (50\%) & 405,262 & 415,575 & 427,013 \\
\hline High (70\%) & 567,367 & 581,805 & 597,819 \\
\hline
\end{tabular}

Four long-term FP services are part of the OBA package. Calculating the proportion of usage using PwC 2012 claims data, the proportions are as follows:

- Sterilisation: $3 \%$

- IUDs: $6.0 \%$

- Implants: $91 \%$

Family planning services provided by the OBA scheme also include vasectomy services for men. However, the uptake of these services has been extremely low with only a handful of cases (in 2012 there were only 2). Therefore, for the purpose of projections, vasectomy services have not been factored in. Further research needs to be done to determine whether these services should be offered at all, and if they are, what sensitization activities would be more effective in creating demand.

For the purpose of this study, it is assumed that the women under the coverage target will use one of the three forms of available contraceptive method under the OBA program in proportion to 2012 trends.

The table below summarises the estimated reimbursement rates for each of the FP services adjusted for inflation using the 2012 reimbursement rates calculated from PwC 2012 claims data (see Annex A). 
TABLE 15: Unit costs of FP services provided under the OBA voucher

\begin{tabular}{|l|l|l|l|}
\hline Service & $\begin{array}{l}\text { Reimbursement } \\
\text { rates } \\
2013(\text { KSh) }\end{array}$ & $\begin{array}{l}\text { Reimbursement } \\
\text { rates } \\
2014 \text { (KSh) }\end{array}$ & $\begin{array}{l}\text { Reimbursement rates } \\
2015 \text { (KSh) }\end{array}$ \\
\hline Sterilisation & 3,728 & 4,033 & 4,460 \\
\hline IUDs & 2,336 & 2,527 & 2,795 \\
\hline Implants & 2,352 & 2,544 & 2,814 \\
\hline
\end{tabular}

Using the data presented in the tables above, the costs of scaling up the OBA program to meet $30 \%, 50 \%$, and $70 \%$ of the unmet need among poor Kenyan women are reported below. The administrative costs of the program have been calculated separately in Section 4.4.

The total family planning costs for each year with related administration costs are presented below (Table 16).

TABLE 16: Summary family planning scale-up costs

\begin{tabular}{|l|r|r|r|r|r|r|r|r|r|}
\hline & \multicolumn{3}{|c|}{$30 \%$ coverage } & \multicolumn{3}{|c|}{$50 \%$ coverage } & \multicolumn{3}{|c|}{$70 \%$ coverage } \\
\hline KSh millions: & 2013 & 2014 & 2015 & 2013 & 2014 & 2015 & 2013 & 2014 & 2015 \\
\hline $\begin{array}{l}\text { Reimbursement } \\
\text { costs }\end{array}$ & 582 & 645 & 733 & 970 & 1,076 & 1,222 & 1,357 & 1,506 & 1,711 \\
\hline Admin costs & 128 & 114 & 100 & 213 & 190 & 167 & 298 & 266 & 233 \\
\hline TOTAL COSTS & 709 & 759 & 833 & 1,182 & 1,265 & 1,389 & 1,655 & 1,771 & 1,945 \\
\hline US\$ millions: & & & & & & & & & \\
\hline $\begin{array}{l}\text { Reimbursement } \\
\text { costs }\end{array}$ & 7 & 8 & 8 & 11 & 13 & 14 & 16 & 17 & 20 \\
\hline Admin costs & 1 & 1 & 1 & 2 & 2 & 2 & 3 & 3 & 3 \\
\hline TOTAL COSTS & 8 & 9 & 10 & 14 & 15 & 16 & 19 & 20 & 22 \\
\hline
\end{tabular}

With approximately US $\$ 14$ million in 2013 , the OBA programme could cover $50 \%$ of the unmet need for contraception among poor Kenyan women.

Reproductive health expenditure is estimated at KShs 38.01 billion in 2013 (see Annex D for calculations). Therefore, the family planning component of that to achieve $50 \%$ coverage in 2013 (including related administration costs) would be 3.1\% of total reproductive health expenditure.

\subsection{Total Costs}

The combined scale-up costs for the safe motherhood and family planning services in US\$ for three different coverage targets will be: 
TABLE 17: Total cost of scale-up for three coverage targets across three years

\begin{tabular}{|c|c|c|c|}
\hline & 2013 & 2014 & 2015 \\
\hline & \multicolumn{3}{|c|}{ (USD \$) } \\
\hline \multicolumn{4}{|c|}{ Total programme costs* } \\
\hline Low & $19,147,118$ & $21,268,118$ & $22,538,445$ \\
\hline Medium & $31,911,864$ & $35,446,863$ & $37,564,075$ \\
\hline High & $44,676,610$ & $49,625,608$ & $52,589,705$ \\
\hline \multicolumn{4}{|c|}{ Administrative costs ${ }^{\wedge}$} \\
\hline Low & $4,203,026$ & $3,753,197$ & $3,073,424$ \\
\hline Medium & $7,005,043$ & $6,255,329$ & $5,122,374$ \\
\hline High & $9,807,061$ & $8,757,460$ & $7,171,323$ \\
\hline \multicolumn{4}{|c|}{ TOTAL COSTS (US\$) } \\
\hline Low & $23,350,144$ & $25,021,315$ & $25,611,869$ \\
\hline Medium & $38,916,907$ & $41,702,192$ & $42,686,448$ \\
\hline High & $54,483,670$ & $58,383,069$ & $59,761,028$ \\
\hline
\end{tabular}

* Safe motherhood and family planning representing $82 \%$ of total costs in $2013,85 \%$ in 2014 ; and $88 \%$ in 2015

^ $18 \%$ in 2013; $15 \%$ in 2014; and $12 \%$ in 2015

In 2013, to achieve 50\% coverage of institutional deliveries and meet the unmet need for contraception amongst poor Kenyan women, the total funding required will be approximately US\$ 38.9 million.

The NHA 2009/10 proportion of reproductive health expenditure as a percentage of THE was $13.9 \%$ and this percentage has been applied to 2013 to 2015 . The figures show that, for example, in 2013 with 50\% coverage, the above total costs of KSh 3,383 million (safe motherhood, family planning and administrative costs) would comprise $1.3 \%$ of THE and $9.2 \%$ of estimated reproductive health expenditure.

The gender-based violence recovery vouchers have still not gained a foothold in the target population and further research is required to estimate both its impact and potential for scale up in the future.

\subsection{Increased Reimbursement Levels}

One of the recommendations from the PWC review is to increase reimbursement levels as some facilities are opting out of the OBA scheme due to low reimbursements. If reimbursement levels are increased by $5 \%$ and year on year inflation rates applied, the total costs increase by $5 \%$ as follows: 
TABLE 18: Total cost of scale-up for three coverage targets across three years with increased reimbursement levels (KShs)

\begin{tabular}{|l|r|r|r|r|r|r|r|r|r|}
\hline KSh millions & \multicolumn{2}{|c|}{$30 \%$ coverage } & \multicolumn{3}{|c|}{$50 \%$ coverage } & \multicolumn{3}{|c|}{$70 \%$ coverage } \\
\hline & 2013 & 2014 & 2015 & 2013 & 2014 & 2015 & 2013 & 2014 & 2015 \\
\hline $\begin{array}{l}\text { Safe } \\
\text { motherhood }\end{array}$ & 1,137 & 1,243 & 1,282 & 1,895 & 2,072 & 2,136 & 2,653 & 2,901 & 2,990 \\
\hline $\begin{array}{l}\text { Family } \\
\text { planning }\end{array}$ & 611 & 678 & 770 & 1,018 & 1,129 & 1,283 & 1,425 & 1,581 & 1,797 \\
\hline $\begin{array}{l}\text { PROGRAM } \\
\text { COSTS }\end{array}$ & 1,748 & 1,921 & 2,052 & 2,913 & 3,201 & 3,419 & 4,078 & 4,482 & 4,787 \\
\hline Admin costs & 384 & 339 & 280 & 639 & 565 & 466 & 895 & 791 & 653 \\
\hline TOTAL COSTS & 2,132 & 2,260 & 2,331 & 3,552 & 3,766 & 3,885 & 4,973 & 5,273 & 5,440 \\
\hline
\end{tabular}

The above figures reflected in US\$ (with some rounding differences) are:

TABLE 19: Total cost of scale-up for three coverage targets across three years with increased reimbursement levels (US\$)

\begin{tabular}{|l|r|r|r|r|r|r|r|r|r|}
\hline US\$ millions & \multicolumn{3}{|c|}{$30 \%$ coverage } & \multicolumn{3}{|c|}{$50 \%$ coverage } & \multicolumn{3}{|c|}{$70 \%$ coverage } \\
\hline & 2013 & 2014 & 2015 & 2013 & 2014 & 2015 & 2013 & 2014 & 2015 \\
\hline $\begin{array}{l}\text { Safe } \\
\text { motherhood }\end{array}$ & 13 & 14 & 15 & 22 & 24 & 25 & 31 & 34 & 34 \\
\hline $\begin{array}{l}\text { Family } \\
\text { planning }\end{array}$ & 7 & 8 & 9 & 12 & 13 & 15 & 16 & 18 & 21 \\
\hline $\begin{array}{l}\text { PROGRAM } \\
\text { COSTS }\end{array}$ & 20 & 22 & 24 & 33 & 37 & 39 & 47 & 52 & 55 \\
\hline Admin costs & 4 & 4 & 3 & 7 & 7 & 5 & 10 & 9 & 8 \\
\hline TOTAL COSTS & 24 & 26 & 27 & 41 & 44 & 45 & 57 & 61 & 63 \\
\hline
\end{tabular}

The change in reimbursement rates from the combined increase in $5 \%$ in reimbursement rates and increase in inflation leads to an overall increase in $20 \%$ between the reimbursement rates from 2012 to 2013. However, the safe motherhood, family planning and administration costs increase by $5 \%$ between the estimates before and after the reimbursement level increases. Annex $\mathrm{E}$ details the increased reimbursement rates that were applied to obtain the above estimates.

Therefore, 50\% coverage in 2013 costing KSh 3,552 million, would represent 1.3\% of THE and 9.3\% of reproductive health expenditure.

\section{CONCLUSION: WAY FORWARD}

The Government of Kenya OBA vouchers program is an affordable strategy to meet the international and national objectives for improved maternal and reproductive health. Maternal health has received significant attention in Kenya both at a national as well as international level. To help achieve the global MDGs related to maternal and child health, especially MDG 5 , the Kenya government has launched several initiatives including NHSSP II, Maternal and Newborn 
health $(\mathrm{MNH})$ roadmap, Contraceptive Security Strategy and the National Reproductive Health Strategy.

Nationally, the Kenya Vision 2030 strives to achieve middle-income country status by the year 2030. Health is a key component of this Vision with a focus on developing equitable financing mechanisms that channel output-based funds directly to healthcare facilities. This output-based approach will help strengthen the evolution of a national social health insurance scheme that serves the informal sector and the destitute.

As a Vision 2030 flagship program, the OBA scheme harmonizes global and national objectives by improving access and enhancing equity in health service delivery. The three maternal health MDG indicators: maternal mortality rate, rate of institutional deliveries and contraceptive prevalence can all be improved substantially by scaling up the OBA program.

The cost of scaling OBA will increase the number of new users and poor women accessing reproductive healthcare with significant contribution to the achievement of the MDGs in Kenya, particularly by contributing to the reduction of maternal mortality. In addition, with the increased efficiency and availability of resources at healthcare facilities, the quality of health care is likely to improve. There will, however, be several challenges to managing such a large-scale program. The $\mathrm{MOH}$ and PMU will have to have greater capacity and robust management systems to ensure the program runs smoothly. There may be logistical challenges, especially to accredit and monitor a large number of service providers and verify service delivery. As part of the drive to improve efficiency, utilization of distributed vouchers will need to be improved. Complementary services could be added to improve utilization, such as including a transport subsidy and increasing sensitization activities. This will, however, lead to higher program costs. Finding the right reimbursement rate for facilities will be an important activity that will need to be repeated on a periodic basis. The risk of losing health care facilities due to low reimbursement levels will need continuous monitoring to ensure there are a suitable number of participating facilities in all areas to ensure access. Routine performance monitoring of utilization, quality, costs, equity and health status will allow program managers to respond and improve operations over time. Overall, planning for a scaled up program should take account of the valuable lessons from the pilot OBA scheme to enhance the scaled up program as far as possible and minimize potential risks and challenges. 


\section{Annex A}

Cost calculations and proportions for 2012 (PwC claims data)

\begin{tabular}{|c|c|c|c|c|c|c|c|c|}
\hline $\begin{array}{l}\text { Safe } \\
\text { motherhood }\end{array}$ & \multicolumn{2}{|c|}{ ANC } & \multicolumn{2}{|c|}{ Normal } & \multicolumn{2}{|c|}{ Caesarean } & \multicolumn{2}{|c|}{ Complication } \\
\hline & $\begin{array}{r}\text { Number } \\
\text { of } \\
\text { patients }\end{array}$ & $\begin{array}{r}\text { Amount } \\
\text { (KShs) }\end{array}$ & $\begin{array}{r}\text { Number } \\
\text { of } \\
\text { patients }\end{array}$ & $\begin{array}{r}\text { Amount } \\
\text { (KShs) }\end{array}$ & $\begin{array}{r}\text { Number } \\
\text { of } \\
\text { patients }\end{array}$ & $\begin{array}{r}\text { Amount } \\
\text { (KShs) }\end{array}$ & $\begin{array}{r}\text { Number } \\
\text { of } \\
\text { patients }\end{array}$ & $\begin{array}{r}\text { Amount } \\
\text { (KShs) }\end{array}$ \\
\hline & 35,586 & $34,784,007$ & 32,046 & $146,993,260$ & 3,857 & $80,803,793$ & 8,738 & $25,126,750$ \\
\hline $\begin{array}{l}\text { Total } \\
\text { deliveries }\end{array}$ & Normal a & d Caesarean & 35,903 & & & & & \\
\hline $\begin{array}{l}\text { Average cost } \\
2012^{*}\end{array}$ & & 977 & & 4,587 & & 20,950 & & 2,876 \\
\hline Percentages+ & $99 \%$ & & $89 \%$ & & $11 \%$ & & $24 \%$ & \\
\hline
\end{tabular}

* Amount divided by number of patients

+ Based on total deliveries of 35,903

\begin{tabular}{|c|c|c|c|c|c|c|c|c|}
\hline \multirow[t]{2}{*}{$\begin{array}{l}\text { Family } \\
\text { planning }\end{array}$} & \multicolumn{2}{|c|}{ BTL } & \multicolumn{2}{|c|}{ Vasectomy } & \multicolumn{2}{|c|}{ Implants } & \multicolumn{2}{|c|}{ IUCD } \\
\hline & $\begin{array}{r}\text { Number } \\
\text { of } \\
\text { patients } \\
\end{array}$ & $\begin{array}{r}\text { Amount } \\
\text { (KShs) }\end{array}$ & $\begin{array}{r}\text { Number of } \\
\text { patients }\end{array}$ & $\begin{array}{r}\text { Amount } \\
\text { (KShs) }\end{array}$ & $\begin{array}{r}\begin{array}{r}\text { Number } \\
\text { of } \\
\text { patients }\end{array} \\
\end{array}$ & $\begin{array}{r}\text { Amount } \\
\text { (KShs) }\end{array}$ & $\begin{array}{r}\text { Number } \\
\text { of } \\
\text { patients } \\
\end{array}$ & $\begin{array}{r}\text { Amount } \\
\text { (KShs) }\end{array}$ \\
\hline & 549 & $1,797,150$ & 2 & 6,000 & 18,261 & $37,706,950$ & 1,162 & $2,383,150$ \\
\hline $\begin{array}{l}\text { Total } \\
\text { patients }\end{array}$ & & & & & & & & \\
\hline $\begin{array}{l}\text { Average } \\
\text { cost 2012* }\end{array}$ & & 3,273 & & 3,000 & & 2,065 & & 2,051 \\
\hline Proportions^ & & 0.03 & & 0.00 & & 0.91 & & 0.06 \\
\hline
\end{tabular}

* Amount divided by number of patients

$\wedge$ Number of patients under each service divided by total number of patients 


\section{Annex B}

\section{Division across quintiles, from Page 120, KDHS 2008/09}

\begin{tabular}{|c|c|c|c|c|c|c|c|c|}
\hline \multirow[b]{2}{*}{$\begin{array}{l}\text { Background } \\
\text { characteristic }\end{array}$} & \multicolumn{2}{|c|}{ Health facility } & \multirow[b]{2}{*}{ Home } & \multirow[b]{2}{*}{ En route } & \multirow[b]{2}{*}{$\begin{array}{l}\text { Other/ } \\
\text { missing }\end{array}$} & \multirow[b]{2}{*}{ Total } & \multirow{2}{*}{$\begin{array}{c}\text { Percentage } \\
\text { delivered } \\
\text { in a health } \\
\text { facility }\end{array}$} & \multirow[b]{2}{*}{$\begin{array}{l}\text { Number } \\
\text { of births }\end{array}$} \\
\hline & $\begin{array}{l}\text { Public } \\
\text { sector }\end{array}$ & $\begin{array}{l}\text { Private } \\
\text { sector }\end{array}$ & & & & & & \\
\hline \multicolumn{9}{|l|}{ Mother's age at birth } \\
\hline$<20$ & 37.3 & 9.3 & 52.6 & 0.6 & 0.3 & 100.0 & 46.6 & 953 \\
\hline $20-34$ & 32.0 & 10.7 & 56.2 & 0.8 & 0.3 & 100.0 & 42.7 & 4,234 \\
\hline $35-49$ & 27.2 & 9.0 & 61.4 & 1.8 & 0.5 & 100.0 & 36.2 & 665 \\
\hline \multicolumn{9}{|l|}{ Birth order } \\
\hline 1 & 47.2 & 13.9 & 37.7 & 0.9 & 0.3 & 100.0 & 61.1 & 1,310 \\
\hline $2-3$ & 33.8 & 11.9 & 53.5 & 0.7 & 0.2 & 100.0 & 45.7 & 2,225 \\
\hline $4-5$ & 23.6 & 9.3 & 65.8 & 1.1 & 0.2 & 100.0 & 32.9 & 1,252 \\
\hline $6+$ & 21.2 & 3.6 & 73.3 & 1.3 & 0.6 & 100.0 & 24.8 & 1,066 \\
\hline \multicolumn{9}{|l|}{ Antenatal care visits ${ }^{1}$} \\
\hline None & 5.1 & 5.6 & 87.5 & 1.2 & 0.6 & 100.0 & 10.7 & 290 \\
\hline $1-3$ & 29.7 & 8.5 & 60.7 & 1.1 & 0.1 & 100.0 & 38.2 & 1,730 \\
\hline $4+$ & 44.6 & 15.7 & 38.4 & 1.3 & 0.1 & 100.0 & 60.3 & 1,872 \\
\hline \multicolumn{9}{|l|}{ Residence } \\
\hline Urban & 51.6 & 23.1 & 24.5 & 0.3 & 0.6 & 100.0 & 74.7 & 1,074 \\
\hline Rural & 28.0 & 7.4 & 63.3 & 1.1 & 0.3 & 100.0 & 35.4 & 4,777 \\
\hline \multicolumn{9}{|l|}{ Province } \\
\hline Nairobi & 45.7 & 43.7 & 9.9 & 0.0 & 0.7 & 100.0 & 89.4 & 334 \\
\hline Central & 56.7 & 16.2 & 25.9 & 1.0 & 0.1 & 100.0 & 73.0 & 466 \\
\hline Coast & 38.0 & 6.4 & 54.6 & 0.7 & 0.3 & 100.0 & 44.4 & 495 \\
\hline Eastern & 33.5 & 9.3 & 54.8 & 2.0 & 0.4 & 100.0 & 42.8 & 890 \\
\hline Nyanza & 34.7 & 9.4 & 54.9 & 0.9 & 0.0 & 100.0 & 44.2 & 1,145 \\
\hline Rift Valley & 26.0 & 6.8 & 66.3 & 0.7 & 0.3 & 100.0 & 32.9 & 1,642 \\
\hline Western & 19.1 & 6.3 & 73.3 & 0.9 & 0.5 & 100.0 & 25.3 & 703 \\
\hline North Eastern & 16.6 & 0.7 & 81.3 & 0.0 & 1.4 & 100.0 & 17.3 & 178 \\
\hline \multicolumn{9}{|l|}{ Mother's education } \\
\hline No education & 12.3 & 2.8 & 83.5 & 0.7 & 0.6 & 100.0 & 15.0 & 763 \\
\hline Primary incomplete & 23.6 & 4.4 & 70.8 & 0.9 & 0.3 & 100.0 & 28.0 & 1,952 \\
\hline Primary complete & 37.1 & 10.9 & 51.0 & 0.9 & 0.1 & 100.0 & 48.1 & 1,761 \\
\hline Secondary+ & 49.6 & 22.0 & 27.0 & 1.0 & 0.3 & 100.0 & 71.6 & 1,375 \\
\hline \multicolumn{9}{|l|}{ Wealth quintile } \\
\hline Lowest & 16.0 & 2.1 & 80.9 & 0.8 & 0.3 & 100.0 & 18.0 & 1,445 \\
\hline Second & 23.1 & 7.3 & 68.3 & 1.1 & 0.2 & 100.0 & 30.4 & 1,190 \\
\hline Middle & 36.2 & 5.4 & 56.7 & 1.4 & 0.3 & 100.0 & 41.6 & 1,085 \\
\hline Fourth & 39.9 & 11.6 & 47.2 & 1.2 & 0.2 & 100.0 & 51.4 & 1,038 \\
\hline Highest & 52.9 & 28.0 & 18.4 & 0.1 & 0.6 & 100.0 & 80.9 & 1,095 \\
\hline Total & 32.3 & 10.3 & 56.2 & 0.9 & 0.3 & 100.0 & 42.6 & 5,852 \\
\hline
\end{tabular}

Note: Total includes 81 women with information missing on number of antenatal visits.

${ }^{1}$ Includes only the most recent birth in the five years preceding the survey 


\section{Annex C}

Financial data, www.tradingeconomics.com/kenya/forecast

\begin{tabular}{|c|c|c|c|c|c|c|c|c|}
\hline MARKETS & REFERENCE & PREVIOUS & ACTUAL & TREND & 2013 & 2014 & 2015 & \\
\hline GOVERNMENT BOND $10 \mathrm{Y}$ & Mar/2013 & 13.50 & 12.30 & & 12.32 & 11.57 & 11.83 & View \\
\hline STOCK MARKET & Mar/2013 & 4518.59 & 4721.23 & & 4727.84 & 4762.05 & 4763.09 & $\underline{\text { View }}$ \\
\hline CURRENCY & Mar/2013 & 86.10 & 85.66 & & 86.94 & 86.02 & 86.69 & $\underline{\text { View }}$ \\
\hline GDP & REFERENCE & PREVIOUS & ACTUAL & TREND & 2013 & 2014 & 2015 & \\
\hline GDP PER CAPITA & Dec/2011 & 470.58 & 478.22 & & 479.65 & 481.19 & 480.22 & $\underline{\text { View }}$ \\
\hline GDP PER CAPITA PPP & Dec/2011 & 1645.52 & 1709.50 & & 1803.43 & 1836.86 & 1863.61 & $\underline{\text { View }}$ \\
\hline$\underline{\text { GDP }}$ & Dec/2011 & 32.19 & 33.62 & & 35.14 & 35.63 & 35.99 & $\underline{\text { View }}$ \\
\hline GDP GROWTH RATE & Sep/2012 & 0.50 & 2.20 & & 1.07 & 1.14 & 1.16 & View \\
\hline GDP ANNUAL GROWTH RATE & Sep/2012 & 3.30 & 4.70 & & 4.38 & 4.11 & 4.17 & View \\
\hline LABOUR & REFERENCE & PREVIOUS & ACTUAL & TREND & 2013 & 2014 & 2015 & \\
\hline POPULATION & Dec/2011 & 40.51 & 41.61 & & 42.51 & 42.51 & 42.51 & View \\
\hline UNEMPLOYMENT RATE & Dec/2011 & 12.70 & 40.00 & & 49.01 & 52.67 & 55.87 & View \\
\hline PRICES & REFERENCE & PREVIOUS & ACTUAL & TREND & 2013 & 2014 & 2015 & \\
\hline $\begin{array}{l}\text { CONSUMER PRICE INDEX } \\
\text { (CPI) }\end{array}$ & Jan/2013 & 134.25 & 135.62 & & 147.58 & 153.36 & 156.74 & $\underline{\text { View }}$ \\
\hline INFLATION RATE & Feb/2013 & 3.67 & 4.45 & & 13.91 & 8.17 & 10.60 & $\underline{\text { View }}$ \\
\hline MONEY & |REFERENCE & PREVIOUS & ACTUAL & TREND & 2013 & 2014 & 2015 & \\
\hline $\begin{array}{l}\text { FOREIGN EXCHANGE } \\
\text { RESERVES }\end{array}$ & Jun/2012 & 411618.00 & 441861.00 & & 472307.08 & 506038.58 & 527306.49 & $\underline{\text { View }}$ \\
\hline INTEREST RATE & Mar/2013 & 9.50 & 9.50 & & 7.75 & 11.00 & 9.75 & $\underline{\text { View }}$ \\
\hline MONEY SUPPLY M1 & Nov/2012 & 699.00 & 691.20 & & 768.47 & 813.45 & 841.14 & $\underline{\text { View }}$ \\
\hline
\end{tabular}




\section{Annex D}

Total health expenditure estimates for 2013-2015 using KDHS 2011/12 and applying trends shown in NHA 2009/10

\begin{tabular}{|l|r|r|r|r|r|}
\hline (Using KNBS Classification of Expenditure by Purpose, 2009/10- 2011/12) & Billions KSHs \\
\hline Total Government Outlay (estimate) 2011/12 & & & $1,165.53$ \\
\hline & & & & \\
\hline
\end{tabular}

* - assume annual inflationary increase using TradingEconomics estimates 


\section{Annex E}

Safe motherhood

\begin{tabular}{|l|c|c|c|c|}
\hline Service & $\begin{array}{c}\text { Reimbursement } \\
\text { rates } \\
2012(\text { KSh) } \\
-5 \% \text { increase }\end{array}$ & $\begin{array}{c}\text { Reimbursement } \\
\text { rates } \\
2013(\text { KSh) }\end{array}$ & $\begin{array}{c}\text { Reimbursement } \\
\text { rates } \\
2014(\text { KSh) }\end{array}$ & $\begin{array}{c}\text { Reimbursement } \\
\text { rates } \\
2015(\text { KSh) }\end{array}$ \\
\hline ANC & 1,026 & 1,169 & 1,264 & 1,398 \\
\hline Normal delivery & 4,816 & 5,486 & 5,935 & 6,564 \\
\hline Caesarean section & 21,998 & 25,057 & 27,105 & 29,978 \\
\hline Complications & 3,020 & 3,440 & 3,721 & 4,115 \\
\hline
\end{tabular}

Family planning

\begin{tabular}{|l|c|c|c|c|}
\hline Service & $\begin{array}{c}\text { Reimbursement } \\
\text { rates } \\
2012(\text { KSh) } \\
-5 \% \text { increase }\end{array}$ & $\begin{array}{c}\text { Reimbursement } \\
\text { rates }\end{array}$ & $\begin{array}{c}\text { Reimbursement } \\
\text { rates } \\
2013(\text { KSh) }\end{array}$ & $\begin{array}{c}\text { Reimbursement } \\
\text { rates }\end{array}$ \\
\hline Sterilisation & 3,437 & 3,915 & 4,235 & 2015 (KSh) \\
\hline IUDs & 2,154 & 2,453 & 2,654 & 4,683 \\
\hline Implants & 2,168 & 2,470 & 2,672 & 2,935 \\
\hline
\end{tabular}




\section{Annex F}

References

Analysis of Kenya OBA programme data - phase 2, Anna Gorter, June 2012

International Database. (2011). Kenya: Demographic indicators. US Census Bureau. Available at: http://www.census.gov/population/international/data/idb/country.php

Government of Kenya: National Health Accounts 2009/10

IPE Global Private Limited: End of Phase II Evaluation and Phase III Baseline Survey of the Reproductive Health - Output-Based Approach (OBA) Project; Evaluation Report; December 2012;

Kenya National Bureau of Statistics (KNBS) and ICF Macro. (2010). Kenya Demographic and Health Survey 2008-09. Calverton, Maryland: KNBS and ICF Macro.

Ministry of Health. (2006). Kenya National Health Sector Strategic Plan II. Nairobi: MOH.

Ministry of Planning, National Development and Vision 2030. (2003). Vision 2030 - A Globally Competitive and Prosperous Kenya. Nairobi: MPND.

Ministry of Public Health and Sanitation. (2008). Output Based Aid/ Demand Side Financing Of Safe Motherhood In Kenya: A Position Paper For Scale Up. Unpublished

NCAPD. (2008). Reproductive Health - Output based Aid Progress Report Phase I.

PricewaterhouseCoopers

Population Council: Reproductive Health Vouchers Evaluation Team. (2011). The reproductive health vouchers program in Kenya: Summary of findings from program evaluation

Population Reference Bureau. (2011). World Population Data Sheet: The World at 7 Billion. Available at: http://www.prb.org/pdf11/2011population-data-sheet_eng.pdf

PwC Monthly claims data 2012

PwC: OBA Phase II Final Report; November 2011

UNDP. (2007). Kenya: Progress by Goal. MDG Monitor. Available at: http://www.mdgmonitor.org/country_progress.cfm?c=KEN\&cd=404

UNICEF. (2009). Kenya: Statistics. Available at:

http://www.unicef.org/infobycountry/kenya statistics.html 